\title{
Menumbuhkan Kebiasaan Membaca Buku Pelajaran melalui Media Ular Tangga
}

\author{
Erna Nur'aini ${ }^{1}$ \\ ${ }^{1}$ SDN Turi 01, Kota Blitar \\ Email: 18ernanur8@gmail.com
}

\section{Tersedia Online di \\ http://www.jurnal.unublitar.ac.id/ index.php/briliant}

\begin{tabular}{l}
\hline Sejarah Artikel \\
\hline Diterima pada 1 Mei 2017 \\
Disetuji pada 1 November 2017 \\
Dipublikasikan pada 13 \\
November 2017 Hal. $441-447$ \\
\hline
\end{tabular}

Kata Kunci:

Membaca, buku pelajaran, ular tangga,

\section{DOI:}

http://dx.doi.org/10.28926/briliant .$v 2 \mathrm{i} 4.58$

\begin{abstract}
Abstrak: Kebiasaan membaca sebenarnya berbeda dengan minat membaca. Pada kebiasaan membaca, motifnya bukan lagi hanya untuk mendapat pengalaman emosional yang mengasyik $\neg$ kan tetapi juga untuk mendapat informasi atau pengetahuan baru. Permainan ular tangga merupakan salah satu alat permainan yang bisa digunakan sebagai media pembelajaran. Permainan ini dapat dimainkan untuk semua mata pelajaran dan semua jenjang kelas. Dengan permainan ular tangga ini siswa lebih termotivasi untuk membaca buku sebelum maupun sesudah pembelajaran, sehingga kebiasaan membaca buku pelajaran dapat ditumbuhkan.
\end{abstract}

Proses belajar yang efektif dilakukan melalui membaca. Seseorang yang gemar membaca akan memperoleh pengetahuan, informasi, dan wawasan baru yang akan meningkatkan kecerdasan dalam menjawab berbagai permasalahan yang dihadapi. Terlebih di era globalisasi ini, membaca merupakan suatu keharusan bagi siapapun. Tanpa membaca, seseorang akan tertinggal dalam banyak hal.

Sebelum tahun 1990-an yaitu sebelum masuknya internet ke Indonesia, siswa SD, SMP, SMA bahkan mahasiswa telah terbiasa menyelesaikan tugastugasnya dengan membaca buku, majalah ataupun surat kabar. Buku-buku yang beredar tak banyak seperti sekarang, sehingga buku pelajaran bekas sekalipun masih sering dicari untuk dipelajari.

Saat ini jumlah buku terbitan semakin banyak, diiringi dengan perkembangan teknologi yang semakin canggih utamanya internet. Hal ini mengakibatkan jumlah buku yang beredar semakin tidak seimbang dengan minat dan kebiasaan membaca masyarakat Indonesia. Berdasarkan data Badan Pusat Statistik (BPS) dan The United Nation of Education Social and Cultural (Unesco) tahun 2012, jumlah masyarakat yang memiliki minat baca hanya 1:1.000. Artinya, dari 1.000 penduduk Indonesia, hanya satu yang memiliki minat baca. Sisanya, 999 orang, kurang memiliki keinginan untuk membaca. (http://www.republika.co.id/berita/koran/opini-koran/16/07/22/oapl025-minatbaca-yang-rendah)

Jika minat membaca bangsa Indonesia dinilai masih rendah, berarti untuk 
menjadikan membaca sebagai suatu kebiasaan masih merupakan tantangan yang harus dipecahkan oleh berbagai pihak. Saat ini kebanyakan orang lebih terbiasa bermain gadged jika dibandingkan membaca buku. Bahkan pelajar SD sekalipun telah terampil mencari penyelesaian tugas rumah mereka lewat google, sehingga buku-buku utamanya buku pelajaran semakin terabaikan. Hal tersebut tidak boleh dibiarkan tanpa upaya perbaikan.

Buku-buku pelajaran yang dibagikan kepada siswa bertujuan agar dibaca saat pembelajaran di sekolah dan saat belajar di rumah. Namun tak jarang bukubuku tersebut menjadi rusak bukan karena dibaca tetapi hanya dibawa dari rumah ke sekolah dan sebaliknya.

Pengertian kebiasaan membaca sebenarnya berbeda dengan minat membaca. Kebiasaan membaca adalah kegiatan berinteraksi dengan bahan bacaan secara teratur atau berulang. Berdasarkan Kamus Besar Bahasa Indonesia, "minat" berarti kecenderungan hati yang tinggi terhadap sesuatu; gairah yang tinggi terhadap sesuatu; keinginan yang tinggi terhadap sesuatu. Sesuatu itu bisa benda, bisa juga interaksi dengan benda tersebut. Minat baca akan menjadi kebiasaan membaca jika tersedia bahan bacaan yang sesuai untuk dibaca dan ada cukup waktu untuk membaca. Pada kebiasaan membaca, motifnya bukan lagi hanya untuk mendapat pengalaman emosional yang mengasyik $\neg$ kan tetapi juga untuk mendapat informasi atau pengetahuan baru (Meilling Simanjuntak : 47)

Guru berupaya terus meningkatkan minat membaca siswa supaya menjadi kebiasaan membaca baik di dalam kelas maupun di luar kelas. Di dalam kelas, ketika pelaksanaan pembelajaran, kebiasaan membaca diarahkan pada buku-buku pelajaran. Guru memotivasi siswa untuk terbiasa membaca buku pelajaran terlebih dahulu sebelum menyelesaikan tugasnya, sehingga anak tidak asal-asalan ketika menjawab pertanyaan.

Bentuk motivasi yang diberikan oleh guru bisa berupa penyajian materi pembelajaran yang menyenangkan dan kreatif. Hal ini sejalan dengan UndangUndang No. 20 tahun 2003 tentang Sistem Pendidikan Nasional bahwa pendidik dan tenaga kependidikan berkewajiban menciptakan suasana pendidikan yang bermakna, menyenangkan, kreatif, dinamis, dan dialogis.

Dalam rangka memenuhi kewajiban pendidik sebagaimana tertuang dalam undang-undang tersebut, maka guru dapat berinovasi dalam pembelajaran dengan menggunakan media permainan ular tangga.

\section{PEMBAHASAN}

Menurut Suparman (Asyhar, 2012), media merupakan alat yang digunakan untuk menyalurkan pesan dari pengirim pesan kepada penerima pesan. Media merupakan komponen yang sangat penting dalam suatu proses komunikasi. Media sangat penting dalam pembelajaran. Senada dengan pendapat tersebut, Kokom berpendapat bahwa media adalah segala sesuatu yang menyalurkan informasi dari sumber informasi kepada penerima informasi. Sementara Marisa (2013) mendefinisikan media pembelajaran sebagai suatau alat atau bahan yang mengandung informasi atau pesan pembelajaran. Penggunaannya media ditujukan untuk memperlancar jalannya komunikasi dalam proses pembelajaran.

Secara psikologis media pembelajaran memiliki beberapa fungsi, diantaranya yaitu fungsi atensi dan fungsi afektif. Media pembelajaran memiliki fungsi atensi siswa artinya media pembelajaran dapat mengambil perhatian 
(attention catcher) peserta didik terhadap materi yang dibahas. Penggunaan media yang tepat dalam pembelajaran dapat menarik perhatian siswa dan mengkonsentrasikan pikiran peserta didik dalam mempelajari materi. Sedangkan fungsi afektif media pembelajaran adalah dapat menggugah perasaan, emosi dan tingkat penerimaan penolakan terhadap sesuatu sehingga akan menimbulkan sikap dan minat peserta didik terhadap materi pembelajaran. Asyhar (2012 : 36).

Permainan ular tangga merupakan salah satu alat permainan yang bisa digunakan sebagai media pembelajaran. Alat permainan yang tujuan dan penggunaannya untuk media pembelajaran harus dipersiapkan pendidik sesuai dengan derajat kesulitan kompetensi yang akan dicapai. Dalam berbagai kegiatan media pembelajaran permainan akan menentukan tumbuhnya perasaan berhasil pada anak sesuai dengan kemampuan mereka.

Permainan ular tangga merupakan salah satu jenis permainan yang sering dimainkan oleh anak-anak. Permainan ini dimainkan oleh dua orang atau lebih. Permainan ular tangga dapat melatih anak untuk bekerja sama serta melatih anak untuk bertindak sportif (Zuhdi, 2010:192). Menurut Yudha (dalam Zuhdi, 2010:192) bahwa permainan ular tangga merupakan jenis permainan kompetisi yang diarahkan pada kemampuan kerja sama dan sportivitas sehingga mampu merekayasa pengalaman sosial dan moral anak.

Permainan ini dapat dimainkan untuk semua mata pelajaran dan semua jenjang kelas. Di dalamnya terdapat kartu soal yang berisi pertanyaan yang harus dijawab oleh siswa melalui permainan tersebut sesuai dengan jenjang kelas dan mata pelajaran tertentu.

Media Permainan Ular Tangga ini terdiri dari : papan permainan, bidak, dadu dan kartu soal. Papan permainan terbuat dari kertas karton yang terbagi dalam kotak-kotak kecil dan di beberapa kotak digambar sejumlah tangga dan ular yang menghubungkannya dengan kotak lain. Papan permainan bisa didesain dengan memanfaatkan software untuk menggambar seperti coreldraw atau digambar dengan cara manual.

Ada beberapa kelebihan jika kita mendesainnya menggunakan software yaitu gambar lebih rapi, dan akan memudahkan kita untuk mengganti gambargambar dan muatan karakter yang ingin ditanamkan sesuai tema pembelajaran. Selain itu akan lebih mudah bagi pendidik untuk memberbanyak media tersebut jika sewaktu-waktu dibutuhkan. Jika memilih pembuatan papan ular tangga dengan menggunakan software seperti coreldraw. maka pembuatannya dapat diawali dengan menggambar petak berukuran $30 \mathrm{~cm}$ x $30 \mathrm{~cm}$. Kemudian di dalamnya diisi petak-petak kecil berukuran $3 \mathrm{~cm} \times 3 \mathrm{~cm}$, sehingga total petak kecil dalam papan tersebut berjumlah seratus petak. Kemudian tambahkan nomornomor berurutan dari sudut kiri ke kanan mulai dari angka 1. Pada baris kedua arah pemberian nomor dari kanan ke kiri, begitu seterusnya berselang seling sampai dengan petak ke-seratus.

Untuk selanjutnya letakkan gambar ular dan tangga secara menyebar. Papan permainan ular tangga sebagai media pembelajaran bisa dikreasi dengan menambahkan kata-kata mutiara yang bermuatan karakter. Gambar tangga umumnya menunjukkan arah naik ke petak nomor sebagaimana ditunjukkan oleh ujung tangga. Pada pangkal tangga (petak nomor angka kecil) dapat diberi tulisan "gemar mambaca" dan ujung tangga (petak dengan nomor lebih besar) bisa kita beri tulisan "berwawasan luas". Hal tersebut dapat menanamkan karakter kepada 
siswa agar gemar membaca untuk mendapatkan wawasan luas. Sedangkan pada gambar ular yang umumnya menunjukkan turun ke petak nomor lebih kecil dapat kita beri tulisan yang bernada peringatan, misal : pada ekor ular (petak dengan nomor lebih besar) kita tuliskan "malas belajar" maka pada kepala ular (petak dengan nomor kecil) bisa kita tuliskan "tidak naik kelas". Dengan demikian akan tertanam pada siswa bahwa kalau malas belajar maka prestasi akan menurun bahkan tidak naik kelas.

Papan media ular tangga juga dilengkapi dengan gambar-gambar tema yang sesuai dengan bunyi soal pada kartu soal. Gambar tersebut diambil dari buku tematik siswa. Buku tematik yang dimaksud tentunya buku dalam bentuk file menggunakan software seperti adobe reader. Kemudian kita ambil gambar dengan menggunakan tool a snapshot pada software adobe reader. Kemudian letakkan gambar tersebut pada petak dengan nomor yang kita inginkan dengan cara "paste". Peletakan gambar-gambar tersebut berfungsi untuk memudahkan siswa menemukan jawabannya dari buku pelajaran. Karena gambar-gambar yang diambil akan disesuaikan dengan pertanyaan yang ada pada kartu soal. Sehingga jika bidak siswa berhenti pada sebuah gambar, maka siswa langsung membuka buku pelajarannya dengan mencari gambar yang sama seperti yang ditunjukkan gambar pada papan permainan ular tangga.

Papan ular tangga yang telah siap diprint kemudian dicetak pada kertas HVS folio. Lembar HVS cenderung bersifat tipis, utuk itu perlu ditempelkan pada kertas karton supaya lebih tebal, rapi dan menarik untuk dimainkan. Papan yang disediakan sejumlah kelompok dalam kelas untuk memudahkan dalam pengelolaan kelas.

Papan yang telah jadi belum bisa dimainkan tanpa adanya bidak. Bidak dalam Kamus Besar Bahasa Indonesia berarti buah catur yang terdepan; pion; laskar. Bidak dalam permainan ular tangga bisa diartikan pion atau maskot yang digunakan oleh pemainnya sebagai penanda tempat kedudukan dan langkah. Mengingat media permainan ular tangga ini digunakan sebagai pembelajaran maka diharapkan semua siswa aktif mengikutinya. Bidak bisa kita dapatkan di toko mainan. Bidak yang tersedia di toko mainan bervariasi dalam hal ukuran dan warna, namun variasinya terbatas, sehingga sulit bagi guru jika ingin menyiapkan bidak sejumlah siswa di kelas, dan berbeda untuk masing-masing siswa. Untuk itu agar bidak yang digunakan bisa bervariasi sejumlah siswa yang ada di kelas, sebaiknya guru membuat sendiri dari bahan kertas karton tipis yang dilipat menjadi bentuk segitiga. Bidak-bidak tersebut bisa kita beri nomor sesuai dengan nomor absen siswa agar tidak berebut.

Demikian pula dengan dadu. Dadu juga bisa dibuat sendiri dari bahan penghapus pensil yang terbuat dari karet. Caranya dengan memotong penghapus tersebut sehingga membentuk kubus. Karet kubus tersebut kemudian diberi tanda titik menggunakan spidol atau ballpoint dengan jumlah dan tempat titik sebagaimana pada dadu.

Kartu soal dapat kita buat di kertas HVS berwarna. dengan ukuran seperenambelas HVS folio, artinya dalam satu lembar kertas folio bisa dibuat enam belas kartu soal. Kartu soal yang kita sediakan disesuaikan dengan waktu pembelajaran. Sedangkan materi atau muatan yang dituangkan dalam kartu soal sesuai tema pembelajaran yang akan dipelajari. 
Penggunaan media permainan ular tangga dalam pembelajaran: (1) Siapkan satu set media permainan ular tangga sejumlah kelompok yang terbentuk di dalam kelas, lengkap dengan bidak, dadu, dan kartu soal. (2) Bentuk kelompok dengan jumlah anggota 2-4 orang sesuai dengan jumlah siswa di dalam kelas. (3) Sebelum permainan dimulai biarkan anak-anak hompimpah terlebih dahulu untuk menentukan siapa pemain pertama, kedua dan seterusnya. (4) Pemain yang mendapat bagian bermain melempar dadu kemudian berhak menjalankan bidak dengan jumlah yang sama dengan mata yang muncul dalam dadu tersebut. Jika mata dadu muncul 6 maka pemain berhak melempar dadu sekali lagi. (5) Jika bidak berhenti di pangkal tangga maka pemain haru melangkahkan bidaknya naik ke ujung tangga dengan terlebih dahulu membaca kata mutiara yang tertera pada pangkal dan ujung tangga. Demikian juga sebaliknya jika ekor ular maka harus meluncur ke petak di bawahnya sesuai yang ditunjukkan kepala ular dengan terlebih dahulu membaca kata-kata mutiara yang terdapat pada ujung ekor dan kepala ular. (6) Jika siswa berhenti pada gambar maka siswa harus menjawab pertanyaan. (7) Siswa yang dapat menjawab pertanyaan dengan benar akan mendapat nilai point 20 setiap kartu soal. Adanya tantangan ini akan membuat siswa untuk berlomba menjawab pertanyaan dengan benar. Keadaan seperti ini dapat dimanfaatkan agar siswa mau membaca buku pelajarannya. Sehingga dengan demikian akan mendorong siswa terus berupaya memberikan jawaban benar dengan mencari jawaban terlebih dahulu pada buku pelajaran yang dimilikinya. Misalkan pada petak no 4 terdapat gambar dua anak yang sedang bermain ayunan yang diambil dari buku siswa tema 8 halaman 6. Maka siswa yang sampai pada nomor tersebut mengambil kartu soal bernomor 4 dan harus menjawab pertanyaannya. Siswa dapat mencari di buku pelajarannya dengan cara mencari gambar yang sama dengan yang tertera pada petak no 4. Siswa yang menjawab dengan benar akan mendapat nilai 20 point. (8) Siswa yang sudah menyelesaikan 5 pertanyaan dari kartu soal dengan benar dapat nilai 100 . Kemudian siswa tersebut tinggal melanjutkan permainan hingga sampai di petak no 100. (9) Bagi siswa yang belum mencapai 5 kartu soal maka siswa tersebut harus tetap bermain meski telah mencapai petak no 100. Siswa tersebut harus mengulang dari petak nomor 1. (10) Kemenangan kelompok ditentukan dengan ketentuan sebagai berikut : kelompok yang nilai akumulatifnya tertinggi adalah pemenangnya, jika nilai tertinggi diperoleh lebih dari satu kelompok, maka kemenangannya ditentukan oleh kecepatan kelompok tersebut.

Dengan menggunakan media ular tangga ini anak tanpa diperintah atau diminta telah membuka dan membaca buku pelajarannya demi mendapatkan jawaban benar pada setiap soal yang ia terima. Keadaan demikian tentunya sangat kita harapkan untuk dapat menumbuhkan kebiasaan membaca buku pelajaran bagi siswa. Kebiasaan membaca buku pelajaran sangat penting untuk membina prestasi siswa sejak dini.

Setiap media tentunya memiliki kelebihan maupun kelemahan. Kelebihan media pembelajaran ular tangga sebagai berikut: (1) Media ular tangga ini sangat efektif untuk memotivasi siswa agar terbiasa membaca buku pelajaran sebelum pelaksanaan pembelajaran (2) Media ini sangat praktis dan ekonomis serta mudah dimainkan. (3) Dapat meningkatkan antusias siswa dalam menggunakan media pembelajaran ini. (4) Siswa akan menjawab pertanyaan dengan sungguh-sungguh apabila mereka berhenti di kotak pertanyaan. (5) Media 
ini sangat disenangi oleh murid karena banyak terdapat gambar yang menarik dan full colour. (6) Dengan media pembelajaran ular tangga akan menumbuhkan perasaan berhasil pada anak sesuai dengan kemampuan mereka. Kelemahan media ini adalah: (1) Dimungkinkan menimbulkan kejenuhan karena banyaknya pertanyaan yang akan ditemui siswa. (2) Akan menimbulkan kejenuhan pada siswa yang menunggu giliran permainan. (3) Jika kurang pengawasan dari guru dalam proses permainan, keadaan akan kurang terkontrol (4) Tanpa pengawasan yang intensif dari guru, siswa dapat mudah terjebak dalam permainan ular tangganya saja tanpa bisa menyerap nilai-nilai atau tujuan digunakan media pembelajaran ini.

Pelaksanaan pembelajaran dengan menggunakan media permainan ular tangga ini dapat dilakukan untuk memulai materi pembelajaran atau tema baru supaya siswa lebih termotivasi untuk membaca buku pelajaran sebelum pembelajaran. Jika pelaksanaan permainan ular tangga dilakukan sebagai pengayaan maka sebaiknya siswa ditugaskan untuk membaca buku pelajarannya pada materi atau tema tertentu yang telah dipelajari dan tidak diperkenankan membuka buku saat permainan sedang berjalan.

\section{KESIMPULAN}

Dengan permainan ular tangga ini siswa lebih termotivasi untuk membaca buku sebelum maupun sesudah pembelajaran. Motivasi yang tinggi untuk membaca buku dapat menumbuhkan kebiasaan membaca buku khususnya buku pelajaran. Pada saat siswa memainkan permainan ini dan mendapatkan posisi bidaknya pada petak bergambar tertentu, siswa akan membuka buku pelajaran dan mencari gambar sesuai dengan gambar pada papan permainan, kemudian siswa mencari informasi terkait pertanyaan pada kartu soal. Sehingga dapat disimpulkan dengan permainan ular tangga, kebiasaan membaca buku pelajaran dapat ditumbuhkan. Kebiasaan membaca ini pada akhirnya dapat meningkatkan hasil belajar. Hasil belajar siswa yang didapat tidak hanya pada mata pelajaran atau tema tertentu melainkan juga berimbas pada semua materi pembelajaran.

\section{SARAN}

Berdasarkan paparan di atas, maka penulis memberikan saran kepada guru untuk menggunakan media yang menyenangkan dan menarik, seperti media permainan. Media permainan ular tangga pada paparan di atas telah terbukti dapat menumbuhkan kebiasaan membaca buku pelajaran pada siswa baik sebelum pembelajaran ataupun sebagai pengayaan. Selanjutnya guru harus berupaya agar kebiasaan membaca yang telah ada tidak pudar. Media pembelajaran ular tangga ini dapat dikembangkan untuk tujuan pembelajaran yang lain. Penggunaan media sebaiknya diikuti dengan penggunaan model pembelajaran yang sesuai agar tujuan pembelajaran bisa terlaksana dengan efektif dan efisien.

\section{DAFTAR RUJUKAN}

Asyhar, R. 2012. Kreatif Mengembangkan Media Pembelajaran. Jakarta: Referensi Jakarta.

Komalasari, Kokom. 2010. Pembelajaran Kontekstual Konsep dan Aplikasi. Bandung : PT Refika Aditama 
Marisa, dkk. 2013. Komputer dan Media Pembelajaran. Tangerang Selatan: Universitas Terbuka.

Zuhdi, Ahmad. 2010. Menjadi Guru Idola. Yogyakarta: Gen-K Publisher

Simanjuntak, M. 2011). Memaknai Hakikat Minat Baca untuk Tujuan Praktis. Visi Pustaka, 13(3) : 45-49

http://www.republika.co.id/berita/koran/opini-koran/16/07/22/oap1025-minatbaca-yang-rendah 